\title{
Jember Fashion Carnaval (JFC) Dalam Industri Pariwisata Di Kabupaten Jember
}

\author{
Chandra Ayu Proborini
}

Program Studi Pendidikan Seni Budaya, Universitas Negeri Surabaya

E-mail: chaproborini@gmail.com

\begin{abstract}
Fenomena Jember Fashion Carnaval (JFC) yang terjadi di Kabupaten Jember menjadi salah satu latar belakang dilakukannya penelitian ini. Jember yang mempunyai latar belakang masyarakat pandalungan, diantara masyarakatnya terbentuk sebuah karnaval fashion yang saat ini dikenal hingga dunia. Fenomena ini menjadi hal yang menarik, karena Jember tidak mempunyai riwayat sejarah fashion dan dikenal dengan kota santri. JFC yang diprakarsai oleh Dynand Fariz telah menunjukkan eksistensinya selama 14 tahun dan telah berhasil merubah Jember menjadi kota karnaval tingkat dunia. Selain itu JFC menjadi barometer karnaval fashion di Indonesia karena menginspirasi daerah lain untuk membuat karnaval yang serupa. JFC memamerkan busana hasil kreativitas dari peserta yang mengikutinya. Peserta diberikan pelatihan untuk membuat dan memperagakan busana. Adanya proses pelatihan tersebut bertujuan untuk meningkatkan kreativitas peserta sehingga dapat membuat busana yang memiliki standart keindahan tersendiri. Proses tersebut secara tidak langsung membuat JFC mengalami proses komodifikasi, yaitu JFC bertransformasi menjadi event yang layak jual. Berdasarkan latar belakang yang telah diungkapkan, penelitian ini bertujuan untuk mengkaji tumbuh dan berkembangnya JFC diantara masyarakat Jember. Adapun secara spesifik mengkaji tentang latar belakang sosial budaya terbentuknya JFC sebagai industri pariwisata di Kabupaten Jember. Hasil penelitian ini menunjukkan bahwa Jember memiliki ciri khas kultural serta modal yang mendukung tumbuh dan berkembangnya JFC di Jember, sehingga Jember dapat bersaing dengan daerah lain dalam ranah sektor pariwisata.Abstrak memuat uraian singkat mengenai masalah dan tujuan penelitian, metode yang digunakan, dan hasil penelitian. Tekanan penulisan abstrak terutama pada hasil penelitian.
\end{abstract}

Kata kunci: Karnaval Fashion, Pariwisata

\section{Jember Fashion Carnaval (JFC) In Tourism Industry In Jember District}

The phenomenon of Jember Fashion Carnaval (JFC) which occurred in Jember district became one of the backgrounds of conducting this study. Jember which has a background of pandalungan society, among those people hold a fashion carnival which is currently known over the world. This phenomenon has become an interesting thing, because Jember has no history of fashion and it is known as the city of students. JFC initiated by Dynand Fariz who has demonstrated its existence for 14 years and it is successfully changed Jember into a town of carnival in the world level. In addition, JFC becomes a barometer of fashion carnival in Indonesia since it is inspired other regions to make a similar carnival. JFC fashion shows the creativity of the participants' costumes that join it. The participants are also given a training to create and demonstrate the costume. The purpose of the existence of the training process is to increase the creativity of the participants so that they can make a fashion that has its own beauty standard. The process indirectly makes JFC become a process of commodification which transformed into an event which is worth selling. Based on the background which has been explained, this study aims at assessing the growth and development of JFC among Jember's society. For the specific reason, it examines the background of socio-cultural formation of JFC as the tourism industry in Jember. The results of this study indicate that Jember has distinctive features as well as the cultural capital to support the growth and development of JFC in Jember, as a result, Jember can compete with other regions in the tourism sector.

Keywords: Fashion Carnaval, Tourism.

Proses Review : 19 April - 4 Mei 2017, Dinyatakan Lolos : 8 Mei 2017 


\section{PENDAHULUAN}

Tercetusnya sebuah event besar bernama Jember Fashion Carnaval (JFC) menjadi sebuah fenomena yang menarik. Jember yang tidak mempunyai latar belakang sejarah karnaval dan fashion, saat ini telah menjadi kota pelopor karnaval fashion dan barometer karnaval di Indonesia. JFC merupakan peragaan desain busana hasil kreativitas putra-putri daerah Jember yang setiap tahunnya membawakan tema-tema yang unik dan menarik.

Secara visual Jember Fashion Carnaval (JFC) merupakan sebuah seni pertunjukan yang berbentuk karnaval (pawai atau arak-arakan) yang bersifat masa kini. Dalam konteks seni tradisional biasanya pawai atau arak-arakan dilakukan dengan mengarak benda-benda pusaka atau tokoh-tokoh tertentu yang dispesialkan atau diagungkan. Sedangkan JFC merupakan sebuah genre seni pertunjukan masa kini yang menampilkan keindahan hasil kreativitas desain rias busana, dan disajikan secara teatrikal didukung oleh berbagai unsur dan cabang seni di antaranya adalah: seni tari, seni teater, seni musik, dan seni rupa. Sebagai produk seni pertunjukan, JFC memiliki berbagai elemen pendukung pertunjukan meliputi: tema dan cerita, karakter tokoh, gerak tari, dan musik dalam bentuk marching band. Semua elemen tersebut tergabung dalam satu kesatuan bentuk pertunjukan yang sangat khas dan memiliki karakteristik gaya yang spesifik sebagai identitas JFC.

JFC memiliki karakteristik tersendiri dari segi bentuk pertunjukannya. JFC tidak hanya sekedar peragaan busana berjalan saja, tetapi dalam JFC peragaan busana dilakukan dengan menari dan bermain teatrikal. Pada umumnya peragaan busana hanya dilakukan berjalan di atas catwalk dalam ruangan, akan tetapi pada JFC berbeda. Peragaan busana yang dilakukan pada JFC dilakukan diluar ruangan dan berjalan sepanjang jalan kota Jember yaitu antara Alun-alun kota Jember sampai Gedung Olahraga Kaliwates Jember. Selain itu peragaan busana tersebut lebih memberikan sentuhan estetika sebagai sebuah produk seni pertunjukan dalam bentuk karnaval.

Setiap tahun JFC menarik perhatian semua lapisan masyarakat termasuk media massa, oleh karena itu Jember Fashion Carnaval (JFC) dipilih menjadi agenda pariwisata utama Kabupaten Jember. Agenda wisata tersebut diberi nama "Bulan Berkunjung Jember" yang sebutannya disingkat menjadi BBJ. Dipilihnya JFC untuk dimasukkan dalam agenda BBJ merupakan salah satu peluang bagi Pemerintah Kabupaten Jember dalam mengembangkan sektor pariwisata dan meningkatkan perekonomian serta sebagai salah satu upaya dalam mewujudkan label kota kreatif bagi Jember.

Sampai saat ini JFC dapat membuktikan perkembangan esksitensinya, sehingga mampu mendongkrak dunia pariwisata di Jawa Timur dan meningkatkan perekonomian masyarakat Jember. Dalam perspektif dunia kreativitas budaya, JFC merupakan pelopor karnaval modern bagi daerah-daerah dan kota-kota di Indonesia. Dalam kurun waktu 15 tahun, JFC telah memperoleh berbagai penghargaan baik dari dalam maupun luar negeri karena kepeloporannya dalam dunia karnaval modern. Salah satu prestasi yang diperoleh JFC adalah meraih predikat karnaval terbaik Indonesia dan dapat menduduki peringkat keempat untuk karnaval terunik dan terheboh di dunia, setelah Mardi Grass di Amerika Serikat, Rio De Janeiro Brazil, dan The Fastnacht di Jerman (Cakwigi, 2013: 2). Prestasi JFC yang mempunyai popularitas mendunia, secara tidak langsung berdampak positif pada industri patiwisata Kabupaten Jember, sehingga dampak tersebut secara tidak langsung juga memajukan sektor perekonomian Kabupaten Jember. Hal ini dibuktikan dengan pernyataan Arif Tjahyono Kepala Kantor Pariwisata dan Budaya Jember dalam majalah Halo Jember, bahwa saat ini Kabupaten Jember menduduki peringkat ketujuh se Jawa Timur sebagai tempat kunjungan wisatawan dengan jumlah terbanyak (Halo Jember 11, p.29). Selain itu bukti kemajuan perekonomian ditandai dengan meningkatnya Pendapatan Asli Daerah (PAD) yaitu dari sektor pariwisata di Kabupaten Jember dari Rp 2,5 miliar pada tahun 2008 dan naik menjadi Rp 8,5 miliar pada tahun 2013 (www.BERITASATU.com, diakses 6 April 2016).

Penelitian ini secara khusus pengkajiannya lebih mengarah kepada latar belakang sosial budaya terbentuknya JFC sebagai industri pariwisata Kabupaten Jember. Pemilihan topik ini didasarkan pada realitas yang ada bahwa JFC saat ini telah menjadi sebuah produk unggulan pariwisata yang tumbuh di tengah-tengah masyarakat Jember sehingga memberikan dampak yang besar dan nyata dalam kemajuan perekonomian masyarakat Jember 


\section{METODE PENELITIAN}

Penelitian ini menggunakan metode penelitian kualitatif . Penggunaan metode penelitian kualitatif didasarkan pada substansi penelitian yaitu obyek dan kajiannya berhubungan dengan keadaan sosial kultur masyarakatnya Jember. Sehingga dalam penelitian ini pemaparannya bersifat deskriptif yang mengkaji JFC dengan pendekatan kebudayaan sampai tingkat paling dalam. Hal ini sesuai dengan ungkapan Bungin bahwa penelitian kebudayaan diperlukan sebuah pendekatan yang tidak hanya bergerak ditingkat permukaan (surface behaviour), tetapi juga menukik hingga ke tingkat paling dalam (tacid knowledge) (2008: 43). Penelitian ini menggunakan pendekatan deskriptif kualitatif. Pendekatan deskriptif kualitatif merupakan pendekatan yang meneliti bagaimana makna-makna tindakan dari kejadian yang menimpa objek yang diteliti dengan cara mendeskripsikan kejadian dalam penelitian. Penerapannya penelitian JFC dalam industri pariwisata ini, peneliti akan lebih mudah dalam menganalisis dan memahami objek penelitian, yaitu JFC. Secara konkritnya dapat mendeskripsikan makna-makna perilaku masyarakat Jember serta para pelaku pertunjukan JFC agar bisa dipahami secara ilmiah. Beberapa makna tersebut tercermin melalui beberapa tingkah laku manusia sehingga pendekatan deskriptif kualitatif dirasa sangat sesuai dalam proses pengumpulan serta pengkajian datanya.

\section{ANALISIS DAN INTERPRETASI DATA}

Latar Belakang Sosial Budaya Terbentuknya Jember Fashion Carnaval (JFC) sebagai Industri Pariwisata di Kabupaten Jember

\section{Sejarah diselenggarakannya Jember Fashion Carnaval (JFC)}

Penyelenggaraan Jember Fashion Carnaval (JFC), berawal dari adanya sebuah Rumah Mode yang didirikan oleh Dynand Fariz sebagai wujud apresiasi dan kontribusinya dalam dunia fashion. Rumah mode yang bernama Dynand Fariz International High Fashion Center tersebut dikelola oleh kerabat dekat Dynand Fariz. Keberadaan rumah mode tersebut menjadi suatu hal baru yang ada di Kota Jember dan hanya sedikit masyarakat yang tau. Oleh karena itu setiap tahunnya, diadakan sebuah acara Fashion Week yang terinspirasi dari acara rumah mode yang ada di Negara-negara fashion lain. Acara Fashion Week tersebut sebagai misi untuk mengembangkan Rumah Mode agar lebih dikenal oleh masyarakat luas. Acara Fashion Week yang dilakukan adalah mewajibkan seluruh karyawan Dynand Fariz International High Fashion Center memakai busana yang sedang trend di dunia, pada saat itu yang sednag trend adalah motif army, busana tersebut harus dipakai pada saat bekerja selama satu minggu dan harus dipakai dari rumah (Budi Setiawan, komunikasi pribadi, 30 Januari 2014).

Pada tahun 2002, acara Fashion Week yang dilakukan berbeda dengan tahun sebelumnya. Acara Fashion Week pada tahun selanjutnya, dilakukan dengan arak-arakan/pawai para karyawan dengan memakai busana yang didesain kreatif dan unik. Arak-arakan tersebut dilakukan disekitar lingkungan kantor Rumah Mode. Arak-arakan tersebut secara mengejutkan menarik perhatian dari masyarakat Kota Jember. Masyarakat sangat tertarik dengan busana yang didesain dengan kreatif dan dipamerkan dengan cara menari dan berjalan di jalanan. Hal tersebut membuat masyarakat menyambut acara tersebut dengan tanggapan positif dan apresiasi yang baik. Antusias dan tanggapan positif masyarakat, menjadi ide bagi Dynand Fariz untuk membuat acara Fashion Week selanjutnya lebih kreatif dan meriah. Ide tersebut akhirnya disatukan dengan cita-cita Dynand Fariz untuk membuah sebuat karnaval fashion di Jember.

Persiapan acara Fashion Week tahun selajutnya yaitu tahun 2003, dilakukan dengan melakukan persiapan yang matang. Dynand Fariz dan pengelola Rumah Mode menyadari, bahwa persiapan harus dilakukan dengan benar-benar terkonsep, kerena acara yang diselenggarakan bukanlah acara pekan mode seperti tahun sebelumnya. Acara yang akan diselenggarakan adalah sebuah acara karnaval fashion yang diharapkan nantinya dapat menarik perhatian masyarakat Jember. Dynand Fariz menginginkan cara karnaval fashion yang akan diselenggrakan memberikan dampak yang positif bagi Jember, sehingga tidak selesai begitu saja apabila pertunjukannya telah usai. Dynand fariz dan tim membuat visi misi dan konsep untuk membuat karnaval fashion ini kedepannya dapat berkembang menjadi lebih baik, dan menjadi karnaval fashion yang besar sehingga bisa memperkenalkan nama Jember kepada masyarakat luas. 
Visi, misi serta konsep yang dirumuskan pada dasarnya adalah untuk menjadikan jember sebagai kota karnaval dunia dan sebagai kota pelopor karnaval di Indonesia. Konsep tersebut semakin menegaskan bahwa karnaval fashion yang akan diselenggarakan harus sesuai dengan visi dan misi yang telah dirumuskan. Oleh karena itu dalam persiapan menentukan tema dan desain busana yang akan diperagakan, dibutuhkan research terlebih dahulu. Dynand Fariz dan tim melakukan berbagai research tema-tema global dunia yang sedang terjadi serta malakukan inovasi desain busana yang belum pernah ada sebelumnya.

Perencanaan dan persiapan dilakukan sedemikian rupa oleh Dynand Fariz dan tim, agar nantinya karnaval yang diselenggarakan dapat diterima dan mendapatkan sambutan positif dari pemerintah dan masyarakat Jember. Acara karnaval fashion ini pertama kali diselenggarakan di Alun-alun/ Centarl Park kota Jember. Dynand Fariz dan tim memilih tempat ini, didasarkan pada alasan bahwa di alunalun merupakan tempat yang strategis dan banyak masyarakat yang berkumpul di alun-alun untuk melakuakan kegiatan olahraga atau sekedar jalanjalan. Selain tempat pertunjukan, tanggal pelaksanaan juga ditentukan, pada saat itu tanggal pelaksanaan dilakukan pada tanggal 1 Januari 2003 yang bertepatan dengan tahun baru dan hari jadi Kota Jember. Pemilihan tanggal yang bertepatan dengan hari jadi Kota Jember bertujuan agar nantinya pemerintah mendukung, sehingga hal-hal yang berkaitan dengan surat perijinan akan berjalan lancar (Budi Setiawan, komunikasi pribadi, 30 Januari 2014). Seiring dengan hal tersebut, sebuah nama Jember Fashion Carnaval (JFC) menjadi nama yang telah disepakati menjadi nama kegiatan acara tersebut.

Persiapan yang matang telah dilakukan, akan tetapi proses terselenggarnya acara JFC mengalami beberapa kendala. Pada tahap pengajuan proposal kegiatan dan surat ijin penyelenggaraan acara kepada pihak pemerintah. Akan tetapi proses pengajuan surat ijin penyelenggaraan tersebut tidak disambut oleh pemerintah dengan baik. Pada waktu itu pemerintah justru tidak mendukung adanya kegiatan atau penyelenggaraan karnaval fashion. Pemerintah tidak mendukung adanya acara tersebut dengan alasan bahwa acara karnaval fashion bukan merupakan budaya asli daerah Jember.
Hal ini dikarenakan tema yang dibawakan pada saat itu adalah tema yang cenderung menuju pada budaya barat, sedangkan pada waktu itu sedang terjadi gencatan senjata Amerika kepada Irak, selain itu rute yang akan digunakan sebagai catwalk melawan arus lalu lintas (Budi Setiawan, komunikasi pribadi, 30 Januari 2014). Dengan alasan tersebut pemerintah tidak bisa memberikan surat ijin penyelenggaraan, sehingga menjadi sebuah halangan untuk menyelenggarakan JFC.

Adanya larangan dari pemerintah tersebut, tidak menggoyahkan niat Dynand Fariz dalam menyelenggarakan acara karnaval fashion tersebut. Meskipun surat ijin dari pemerintah belum bisa didapatkan, akan tetapi persiapan acara tetap dilakukan. Hal ini sebagai wujud kesungguhan bagi Dynand Fariz dan tim, untuk menyelenggarakan acara yang dikonsep untuk membanggakan nama Jember pada masarakat luas. Dynand Fariz sebagai kreator JFC, tidak putus asa dalam meyakinkan pemerintah bahwa acara tersebut tidak menyalahi budaya yang ada. Presentasi dilakukan beberapa kali kepada pihak-pihak pemerintah yang terkait, untuk menjelaskan visi, misi dan konsep besar dari JFC. Pada akhirnya dua hari sebelum pelaksanaan, Dynand Fariz dan tim berhasil meyakinkan pihak pemerintah, sehingga surat ijin penyelenggaraan acara telah didapatkan dan ditandatangani oleh Bupati Jember tertanggal 31 Desember 2002.

Setelah mendapatkan surat ijin, keesokan harinya yaitu, 1 Januari 2003 penyelenggaraan JFC dilakukan. JFC pertama kali diikuti 50 peserta, yang terdiri dari karyawan rumah mode Dynand Fariz, karyawan salon Karisma milik Suyanto kakak Dynand Fariz, dan Karyawan Salon Dyfa milik Dynand Fariz. Pada waktu itu defile yang dibawakan adalah Cowboy, Punk dan Gipsy (Fefi, komunikasi pribadi, 8 Maret 2014). Penyelenggaraan pertunjukan berlangsung meriah, hal ini didasarkan pada apresiasi dan tanggapan masyarakat yang positif. Beberapa media lokal juga memberitakan penyelenggaraan JFC, meskipun terdapat beberapa media yang memberitakannya secara negatif. Tetapi hal ini menjadi sebuah kebanggaan bagi Dynand Fariz dan tim, karena telah berhasil dalam menyelenggarakan acara yang sebelumnya mengalami beberapa kendala. 
Penelitian ini menggunakan metode penelitian Suksesnya penyelenggaraan pertunjukan JFC tersebut, menjadi pembuktian bagi pemerintah bahwa JFC layak dan mampu membanggakan Jember. Oleh karena itu sebagai tindak lanjut atas keberhasilan tersebut, pemerintah memberikan dukungan serta apresiasi positif bagi JFC. Dukungan dan apresiasi tersebut diwujudkan dengan meminta JFC dilaksanakan kembali pada saat acara perayaan HUT kemerdekaan RI di Jember, yaitu 17 Agustus 2003 serta memberikan kebebasan dalam menggunakan fasilitas dan sarana. Hal tersebut disambut baik oleh Dynand Fariz dan Tim, adanya dukungan pemerintah tersebut menjadi awal berkembangnya JFC. Dalam persiapannya untuk acara HUT kemerdekaan RI di Jember, JFC kali ini secara resmi ditangani oleh manajemen JFC yaitu Jember Fashion Carnaval Council (JFCC). Dibentuknya JFCC bertujuan agar persiapan pertunjukan JFC menjadi lebih fokus dan termanajemen dengan baik. Pada persiapan pertunjukan JFC selanjutnya, pihak JFCC juga melibatkan pemerintah sehingga visi dan misi antara pihak JFCC dan pemerintah satu tujuan.

Seiring dengan berjalannya waktu JFC diselenggrakan setiap tahun. Adanya JFC memberikan inspirasi untuk membuat sebuah serangkaian agenda kegiatan pariwisata bagi Jember. Agenda tahunan tersebut di beri nama "Bulan Berkunjung ke Jember" atau sering disebut dengan BBJ. BBJ pertama kali dilakukan pada tahun 2007, BBJ merupakan sebuah agenda pariwisata sekaligus sebuah manajemen besar yang mewadahi seluruh kegiatan wisata tahunan Kabupaten Jember(“jemberinformationcenter," n.d). BBJ dilaksakan bersamaan dengan perayaan HUT kemerdekaan RI di Jember pada setiap tahunnya. Dalam setiap tahun kegiatan BBJ, JFC merupakan agenda pariwisata utama dalam jadwal kegiatnnya. Hingga pada tahun 2009 JFC ditetapkan sebagai agenda kegiatan tahunan resmi Kabupaten Jember.

Perjalanan JFC untuk menjadikan Jember sebagai kota karnaval tidak berjalan dengan mulus begitu saja. Pada beberapa tahun awal penyelenggaraan., beberapa tokoh ulama di Jember sempat memprotes desain busana yang terlalu terbuka pada waktu itu. Aka tetapi pihak manajemen JFC berusaha mencari solusi tersebut dengan mealkukan dialog dengan beberapa tokoh ulama. Adanya dialog tersebut bertujuan agar kedua pihak tidak terjadi kesalahpahaman yang memunculkan konflik. Dialog tersebut adalah mencari solusi dalam permalahan tersebut. setelah dilakukan dialog oleh kedua pihak, yaitu pihak ulama dan manajemen JFCC, akhirnya didapatkan sebuah solusi yang disepakati. Dalam pertunjukan ke depannya JFC akan tampil dengan busana yang tidak melanggar norma agama akan tetapi tidak mengurangi kekreatifan desain busana dan keindahan busana yang akan diperagakan.

Setiap tahunnya JFC memberikan sajian pertunjukan yang spektakuler, dengan berbagai inovasi yang dilakukan. Sehingga pada perhelatan JFC ke-3 secara tidak sengaja menarik minat media online asing untuk meliput, yaitu Reuters (Wijaya, 2016, April 13). Dengan adanya media asing yang meliput JFC, hal ini menjadi sebuah awal JFC dikenal oleh dunia. Padahal dalam waktu yang bersamaan masih sedikit sekali media lokal yang memberitakan dan meliput tentang JFC. Adanya media asing yang meliput tentang pertunjukan JFC secara otomatis menjadi sebuah gebrakan bagi media lokal (Budi Setiawan, komunikasi pribadi, 30 Januari 2014). Dimana event spektakuler negara sendiri justru diliput oleh media negara asing, sedangkan media lokal sendiri kurang dalam meliput serta memberitakannya. Sejak saat ini banyak sekali media lokal maupaun asing yang ingin meliput, memberitakan serta menyiarkan secara langsung pertunjukan JFC (Fefi, komunikasi pribadi, 8 Maret 2014).

Inovasi selalu dilakukan dalam setiap tahun penyelenggaraan JFC, baik inovasi isi pertunjukan maupun pengelolaan. Inovasi isi pertunjukan yang di ekplorasi adalah tema, desain busana, bahan pembuatan busana, bentuk pertunjukan, dan penambahan unsur pertunjukan yang sesuai. Dalam perkembangannya menambah unsur pertunjukan, JFC menambahkan unsur drama, tari dan music. Salah satu contohnya adalah unsur musik yaitu dengan berkolaborasi dengan Marching Band untuk mendukung pertunjukannya, Marching Band tersebut di berinama JFC Marching Band. Sedangkan inovasi pengelolaan JFC, dilakukan dengan mengembangkan kualitas area pertunjukan, akses pertunjukan dan hal lain yang mendukung terselenggaranya pertunjukan. Inovasi yang dilakukan adalah bertujuan untuk mempertahankan eksistensi dan prestasi JFC. 
Saat ini JFC semakin dikenal oleh dunia, dalam setiap tahun penyelenggaraannya JFC menjadikan Jember sebagai kota destinasi utama para wisatawan, baik wisatawan dalam maupun luar negeri. JFC juga telah menarik banyak perhatian media massa dari dalam maupun luar negeri untuk meliput dan memberitakannya. Setiap menjelang penyelenggaraan JFC, kota Jember menjadi sangat ramai (Job Pamungkas, komunikasi pribadi, 20 Agustus 2015). Dalam waktu 15 tahun keberadaan JFC, JFC telah mendapatkan berbagai prestasi dan penghargaan baik dari dalam maupun luar negeri. Hal ini membuktikan bahwa JFC konsisten dalam menjalan visi dan misinya dalam menjadikan Jember sebagai kota karnaval fashion dunia.

\section{Tokoh Pemrakarsa Jember Fashion Carnaval (JFC): Dynand Fariz}

Keberhasilan pertunjukan JFC dalam membawa nama Jember dikenal oleh dunia, tidak jauh dari seorang kreator yang berada dibaliknya. Tokoh pemrakarsa ini adalah putra daerah Jember asli, yaitu Dynand Fariz. Dynand Fariz saat ini menjadi tokoh besar di Jember akibat karya besarnya membuat pertunjukan karnaval fashion yang dapat mendunia. Dibalik keberhasilannya tersebut tidak sedikit perjuangan dan pengorbanan yang dilakukan oleh Dynand Fariz. Kegigihan dan tekad Dynand Fariz menjadi salah satu faktor terbentuknya JFC.

Dynand Fariz adalah seorang pria kelahiran Desa Garahan, Kecamatan Silo, Kabupaten Jember, Jawa Timur pada 23 Mei 1963. Dynand Fariz merupakan putra ke delapan dari sebelas bersaudara, yang terlahir dari pasangan Alm. Tirto Soetowo dan Alm. Ahyani (Budi Setiawan, komunikasi pribadi, 30 Januari 2014).

Dynand Fariz memulai karirnya di bidang fashion sejak tahun 1988 ketika dia baru lulus dari perguruan tinggi IKIP Surabaya, Jurusan Seni Rupa. Pada saat itu setelah meyelesaikan studinya di IKIP Surabaya, Dynand Fariz diangkat menjadi dosen di almamaternya tersebut, yaitu menjadi dosen Tata Busana di Jurusan Pendidikan Kesejahteraan Keluarga (PKK), Fakultas Teknik. Setelah menjadi dosen, Dynand Fariz merasa kurang puas dan merasa ilmunya kurang berkembang, sehingga Dynand Fariz mencoba untuk mendaftar dalam program beasiswa sekolah mode cabang Paris di Jakarta yaitu Ecole Superieure des Arts et
Techniques de la Mode Established (ESMOD). Akhirnya pada tahun 1996 Dynand Fariz mendapatkan beasiswa untuk belajar di ESMOD Jakarta selama 3 tahun. Selama tiga tahun menimba ilmu di ESMOD Jakarta Dynand Fariz memanfaatkan kesempatan tersebut untuk belajar dan mengasah kemampuannya di bidang fashion. Karir Dynand Fariz semakin meningkat ketika dia menyelesaikan belajarnya di ESMOD. Dynand Fariz melamar sebagai pengajar di ESMOD, kemudian mendapatkan kesempatan untuk mengikuti training teacher dan mendapatkan beasiswa untuk pelatihan mengajar di Paris, Perancis selama tiga bulan. Hal ini semakin menunjukkan bahwa Dynand Fariz merupakan sosok yang mumpuni dalam bidang fashion (Mardiana Pambudy dkk., n.d.).

Dynand Fariz sebagai seorang yang berkiprah di bidang fashion, pada tahun 2000 mendirikan sebuah konsultan mode di Kota Jember yang diberi nama Dynand Fariz International High Fashion Center. Dynand Fariz mendirikan konsultan mode atau rumah mode tersebut sebagai wujud pembuktian karirnya di bidang fashion. Dynand Fariz beranggapan bahwa adanya konsultan mode di Jember sangat penting, karena adanya konsultan mode yang merupakan suatu hal baru di Kota Jember.

Rumah mode yang didirikan oleh Dynand Fariz tersebut dikelola secara profesional dan di bantu oleh saudaran-saudaranya. Setiap tahun rumah mode Dynand Fariz selalu mengadakan event fashion yang bertujuan untuk menunjukkan kepada masyarakat pentingnya fashion dalam kehidupan dan keberadaan rumah mode tersebut. Event inilah yang kemudian menjadi cikal bakal terwujudnya ide besar Dynand Fariz membuat sebuah karnaval fashion yang dikenal dunia yaitu JFC (Fefi, komunikasi pribadi, 8 Maret 2014).

Dynand Fariz sebagai seorang desainer tetap bangga dengan tanah kelahirannya yaitu Jember. Oleh karena itu Dynand Fariz mempunyai cita-cita yaitu membuat Jember ingin lebih dikenal oleh orang. Disamping itu Dynand Fariz mengakui bahwa persaingan dalam dunia fashion sangat berat, akan sulit bagi dirinya untuk bertahan dan menunjukkan eksistensi apabila tidak dapat membuat sebuah inovasi secara terus menerus. Dalam hal ini Dynand Fariz sangat pandai dalam melihat sebuah peluang, dia justru menjadikan kota asal 
kelahirannya sebagai media atau tempat mewujudkan impiannya, yaitu membuat sebuah acara yang dikenal hingga Internasional.

Dynand Fariz sadar bahwa cita-cita tersebut sangat sulit untuk diwujudkan, terlebih lagi hal ini sangat menantang kebudayaan lokal yang ada. Akan tetapi hal tersebut lantas tidak menyurutkan semangatnya dalam berkarya. Research dan perencanaan yang matang dia lakukan dalam mewujudkan karya besarnya tersebut. Awal terbentuknya JFC banyak halangan dan rintangan yang dihadapi. Banyak sekali pihak yang tidak setuju dengan konsep JFC, salah satunya adalah pemerintah. Pihak pemerintah menganggap bahwa karnaval fashion bukan budaya asli Jember. Dalam mengahadapi masalah tersebut, Dynand Fariz berusaha keras dengan menjelaskan konsep dan visi misi yang telah dirancang kepada pihak yang tidak menentang. Kematangan konsep dan visi misi tersebut akhirnya dapat membantu JFC mendapatkan kesempatan untuk terselenggara untuk pertama kalinya.

Keberhasilan JFC sangat dipengaruhi oleh sifat kegigihan Dynand fariz dalam konsisten mewujudkan impian besar dan cita-citanya. Sifat kegigihan Dynand Fariz tersebut dipengaruhi oleh berbagai pengalaman yang sudah dialami. Berasal dari latar belakang keluarga sederhana, justru menjadikan Dynand Fariz sebagai seorang yang bercita-cita besar dalam hal meraih cita-citanya. Sejak kecil Dynand Fariz menjadi seorang yang pekerja keras, hal ini merupakan kebiasaan Dynand Fariz sejak masa kecilnya setelah menyelesaikan kegiatan belajarnya, dia selalu membantu pekerjaan orangtuanya (Mardiana Pambudy dkk., n.d.). Hal tersebut merupakan salah satu faktor bagaimana karakter pekerja keras dan gigih Dynand Fariz terbentuk.

\section{Proses Tumbuh dan Berkembangnya Jember Fashion Carnaval (JFC) diantara Masyarakat Jember}

Dalam menganalisis faktor terbentuknya JFC digunakan teori Bourdieu yaitu, konsep habitus. Menurut Lee (2015: 57) dengan mengembangkan konsep habitus Bourdieu mampu mengembangkan model tindakan sosial yang didalamnya kebudayaan dan relasi kultural memperoleh otonomi relatif, namum nyata, dari relasi produksi. Berdasarkan ungkapan tersebut peneliti mengembangkan model tindakan masyarakat Jember, dan memahami bagaimana relasi kultural masyarakat Jember kaitanya dengan keberadaan JFC.

\section{a. Habitus Masyarakat Kabupaten Jember}

Seperti yang diungkap oleh Lee bahwa habitus merupakan ciri khas kultural. Dalam penelitian ini ciri khas kultural yang dimaksud adalah ciri khas kultural masyarakat Jember. Seperti yang sudah disebutkan pada bab sebelumnya, Jember merupakan kawasan pandalungan dimana masyarakatnya merupakan percampuran yaitu Jawa dan Madura. Akibat bertemunya kedua masyarakat tersebut membuat Jember sebagai wilayah yang masyarakatnya terbuka dengan adanya arus budaya baru. Oleh sebab itu hal ini berdampak pada sulitnya Jember mempunyai kesenian tradisi asli yang dapat dijadikan sebagai ikon. Hal ini sesuai dengan ungkapan Yuswadi dalam Sutarto dan Setya bahwa masyarakat pandalungan lebih bersifat terbuka terhadap adanya arus budaya baru dan sulit untuk mempunyai kesenian tradisi yang mengikon. Akan tetapi keadaan tersebut memberikan celah bagi JFC untuk bisa berkembang di wilayah tersebut. Masyarakat Jember secara terbuka menerima JFC sebagai salah satu budaya mereka, sehingga secara perlahan JFC telah menjadi identitas kota Jember. Selain faktor keadaan kultural masyarakat, terdapat beberapa faktor yang mendukung terbentuknya JFC di Jember. Mengacu pada konsep habitus Bourdieu, Jember memiliki beberapa modal yang menjadikan JFC dapat tumbuh dan berkembang di Kabupaten Jember.

Modal budaya, Jember mempunyai latar belakang masyarakat pandalungan, yaitu bertemunya budaya Madura dan Jawa, yang keduanya saling berinteraksi sehingga kedua masyarakat tersebut terintegrasi dan cenderung terbuka dengan budaya baru. Sifat keterbukaan masyarakat tersebut menjadikan JFC mudah dalam berintegrasi dengan masyarakat Jember. Dalam hal ini JFC menjadi budaya baru yang terbentuk diantara interaksi masyarakat Jawa dan Madura, sehingga JFC menjadi alternatif yang dapat menyatukan keduanya dan masyarakat minoritas yang lain. JFC secara perlahan mengisi celah kosong sebagai identitas kota Jember, meskipun pada awalnya mengalami berbagai kecaman dari beberapa pihak. Akan tetapi JFC berhasil bernegosiasi dengan baik sehingga dapat diterima oleh masyarakatnya. 
Adanya JFC bukan berarti kesenian tradisi yang ada di daerah tidak berkembang, JFC mengajak para seniman daerah untuk berpartisipasi untuk berkolaborasi. Hal ini terbukti ketika JFC mengusung tema Madurese yang berkolaborasi dengan musik Ul daul Madura, dan defile Reog yang berkolaborasi dengan seniman reog. Selain itu berkaitan dengan modal budaya individu kreator JFC, Dynand Fariz merupakan seseorang yang berlatar belakang sekolah fashion bertaraf internasional. Sehingga habitus dunia fashion Dynand Fariz dan modal akademik yang diperoleh dari sekolah fashion bertaraf internasional, sangat mendukung keberlangsungan dan terbentunya JFC.

Modal sosial, dalam hal ini merupakan modal bagaimana pihak-pihak yang bersangkutan dengan JFC menjalin sebuah jaringan atau relasi untuk mendukung terbentunya JFC. Berkaitan dengan hal tersebut sesuai dengan ungkapan Wahab (1996:

185) bahwa lembaga pemerintah dalam membantu kemajuan pariwisata maka membangun dan memantapkan suatu situasi yang layak bagi insvestasi swasta sampai pada pengeluaran ketentuan-ketentuan yang menjamin kestabilan ekonomi, dan secara aktif mempersiapkan para investor dalam pariwisata dengan subsidi-subsidi yang luar biasa. Begitupun dengan pemerintah Jember, pemerintah Jember membangun jaringan secara luas dengan beberapa pihak, agar banyak investor yang mau menanamkan modal di Jember, sehingga mendukung adanya fasilitas bagi para wisatawan yang ingin melihat pertunjukan JFC.

Modal sosial lain yang terlihat adalah cara manajemen dalam mengelola pesertanya. Manajemen secara tidak langsung memproduksi solidaritas kelompok sehingga menjadi modal sosial yang dimiliki. Manajemen JFC mengajak peserta JFC yang terdidik maupun tidak terdidik untuk bergabung dan berpartisipasi pada JFC. Para peserta tersebut diberikan pelatihan secara gratis, sehingga masyarakat tertarik untuk mengikutinya. Adanya program pelatihan yang diberikan kepada peserta, menyebabkab terjadinya proses pembelajaran didalamnya, sehingga mendorong adanya interaksi antar peserta. Adanya proses tersebut secara tidak langsung membentuk solidaritas dan mempunyai satu tujuan bagi para peserta JFC. Modal tersebut memberikan celah bagi JFC untuk lebih bekembang dari sisi bertambahnya jumlah peserta dan menjadikannya sebuah pertunjukan yang besar. Ditinjau dari segi modal sosial kreatornya, Dynand Fariz dalam hal ini membangun relasi yang kuat dengan beberapa lembaga terkait yang mendukung adanya JFC. Relasi tersebut terjalin ketika Dynand Fariz berkarir dalam bidang fashion (sebelum adanya JFC). Salah satu contohnya adalah setiap tahun JFC selalu malakukan roadshow di Jakarta, hal ini merupakan salah satu dampak terjalinnya relasi yang dilakukan oleh Dynand Fariz dalam karirnya dalam bidang fashion.

Modal ekonomi, selama ini JFC merukan event yang membiayai dirinya sendiri. JFC merupakan pertunjukan yang jauh dari bantuan dana sponsor ataupun pemerintah. Tidak adanya sponsor adalah untuk mempertahankan label bahwa JFC sebagai event sosial dan tidak dikomersilkan oleh lembaga tertentu selain menajemen JFC, sedangkan pemerintah hanya membantu dalam pemberian fasilitas. Modal ekonomi JFC pada awalnya terpusat pada satu sumber yaitu dana pribadi Dynand Fariz. Akan tetapi seiring dengan besarnya nama JFC, modal ekonomi diperoleh dari hasil melakukan roadshow dalam maupun luar negeri. Selain itu kompetensi Dynand Fariz dalam bidang fashion didapatkan dari modal ekonomi pribadi dan beasiswa yang didapatkan sehingga menunjang keahliannya dalam bidang fashion.

Keputusan manajemen JFC untuk menyuarakan JFC sebagai lembaga event sosial tersebut, merupakan salah satu strategi untuk membuat JFC jauh dari kesan komersil, dan menghindari pengelolaan keuangan yang rumit. Dengan tidak adanya sponsor yang terlalu mendominasi, secara otomatis JFC berdiri sendiri di bawah naungan manajemen JFCC, sehingga keuangan dikelola sendiri dan lebih mudah pengelolaannya serta prosedurnya.

Dengan habitus dan modal yang dimiliki tersebut, dapat menjabarkan bagaimana JFC dapat terbentuk dan berkembang diantara masyarakat padalungan Jember, dan bahkan saat ini telah menjadi identitas Kota Jember. Pembahasan konsep habitus JFC tidak berhenti dalam penjabaran modal yang dimiliki, akan tetapi konsep ranah juga mempengaruhi bagaimana JFC terbentuk 


\section{b. Arena Persaingan dalam Industri Pariwisata}

Konsep habitus dan arena merupakan relasi dua arah, hubungan tersebut dapat dijelaskan bahwa dengan miliki habitus yang mendukung maka JFC dapat bersaing dalam arena sosial yang ditargetkan, begitupun sebaliknya dalam sebuah arena sosial dibutuhkan kompetitor untuk mengisi arena terebut. Terkait dengan penelitian ini arena yang dimaksud adalah persaingan dunia industri pariwisata. Untuk dapat bersaing dalam dunia industri kreatif dan pariwisata, JFC memiliki habitus dan modal yang mendukung seperti yang sudah dijabarkan diatas. Untuk memenangkan persaingan tersebut JFC mewujudkannya dalam bentuk karnaval fashion yang memperagakan busana dari hasil kreativitas yang tinggi. Sehingga JFC dapat meraih posisi sebagai pertunjukan kreativitas tinggi yang bertaraf internasional dan meningkatkan industri pariwisata Jember. Seperti yang sudah diungkap oleh Jenkins bahwa pembahasan arena mengarah pada tiga hal.

Pertama, hubungan arena dengan "arena kekuasaan" (politik) harus dipahami. Dalam hal ini pemerintah kota Jember menjadikan JFC sebagai tombak untuk menjadikan JFC sebagai agenda pariwisata utama dalam program BBJ. Hal ini bertujuan agar dunia pariwisata Jember meningkat sehingga Jember dapat bersaing dengan kota lain dalam hal wisata budaya dan penggalakan Kota kreatif. Tujuan pemerintah berjalan seiring dengan visi dan misi JFC dalam menjadikan Jember sebagai kota karnaval fashion dunia. Hubungan tersebut memberikan dampak positif bagi keduanya. Sehingga saling mendukung dalam proses pelaksanannya.

Kedua, dalam arena orang harus mengkontruksi suatu "topologi sosial" atau peta "struktur objektif" dari posisi yang menciptakan arena, dan hubungan antara mereka dalam kompetisi dengan bentuk spesifik dari modal. Dalam hal ini manajemen JFC menganalisis bagaimana JFC dapat tumbuh dan berkembang di Jember. Hal ini terlihat ketika Dynand Fariz mendirikan Rumah Mode di Kota Jember, serta membentuk JFC di Kota Jember yang tidak memiliki riwayat tentang sejarah fashion. Dynand Fariz dan manajemen mampu dalam memahami terciptanya arena persaingan, sehingga JFC dipersiapkan untuk memiliki modal yang kuat dan dapat bersaing merebut target arena yang diinginkan.
Ketiga, habitus manusia di dalam arena harus dianalisis, bersama dengan jejak atau strategi yang diproduksi dalam interaksi antara habitus dan kendala serta kesempatan yang ditentukan oleh struktur arena. Keadaan kultural masyarakat Jember dapat dibaca dengan baik oleh Dynand Fariz dan manajemen. Pihak manajemen selalu mengadakan dialog dan negosiasi apabila mendapatkan kritik dari pihak yang kurang mendukung adanya JFC. Sehingga pihak manajemen dapat mengatur srtategi untuk bernegosiasi dengan masyarakat Jember secara damai, sehingga JFC dapat mecapai tujuan yang diinginkan yaitu menjadi karnaval fashion yang bertaraf intenasional yang didukung oleh masyarakatnya.

\section{Kreativitas Kreator Jember Fashion Carnaval (JFC): Dynand Fariz}

Dibalik prestasi JFC hingga mendunia, hal tersebut tidak jauh dari peran sang kreator Dynand Fariz dibaliknya. Dynand Fariz sebagai presiden JFC memiliki kontribusi tinggi pada proses terbentuknya JFC. Kontribusi yang diberikan Dynand Fariz kepada JFC tidak hanya kontribusi ide idenya yang kreatif tetapi juga secara materi. Hal tersebut dilakukan karena Dynand Fariz merasa bertanggungjawab atas semua yang berhubungan dengan JFC.

Secara personal, Dynand Fariz merupakan sosok yang kreatif dan inovatif, karena Dynand Fariz mampu dan mau untuk mewujudkan ide-idenya. Dynand Fariz mampu mengembangkan idenya sehingga bisa terwujud menjadi sebuah karya yang memiliki standar keindahan tersendiri. Tabrani mengungkapkan bahwa, ciri manusia kreatif adalah ketika manusia tersebut memiliki beberapa sifat yaitu, ada dorongan bermain, intuisi, imajinasi, estetika, sikap keterbukaan, keberanian, dan spontan (2006: 243-249). Mengacu pada ungkapan Tabrani tersebut, apabila dilihat melalui prosesnya Dynand Fariz memenuhi kriteria sebagai manusia kreatif, karena memiliki sifat-sifat yang diungkap oleh Tabrani. Adapun penjelasannya sebagai berikut.

Ada dorongan bermain, ciri tersebut dapat dilihat ketika Dynand Fariz menjabat sebagai dosen di Universitas Negeri Surabaya, akan tetapi dia belum merasa puas dengan pekerjaan yang dijalani karena merasa ingin lebih mengembangkan 
kemampuannya dibidang fashion. Oleh karena itu dia memutuskan untuk belajar lagi di sekolah fashion ESMOD. Setelah menyelesaikan belajarnya di ESMOD, Dynand Fariz mencoba untuk mendaftar sebagai staf pengajar di ESMOD. Hal tersebut membuktikan bahwa sosok Dynand Fariz merupakan sosok yang mempunyai dorongan untuk bisa merubah hidupnya, dengan berani menantang dan menanggung resiko yang akan diterima.

Intuisi, ciri tersebut dimiliki oleh Dynand Fariz dengan melihat proses ketika Dynand Fariz memutuskan untuk memilih dunia fashion untuk mengembangkan bakatnya. Pilihan tersebut tentunya melibatkan perasaan dari Dynand Fariz, dan perasaan tersebut bersifat kuat sehingga mendukung adanya aksi dari adanya sifat dorongan. Adanya sifat dorongan tidak berarti ketika tanpa intuisi (Tabrani, 2006: 245). Ungkapan tersebut menghubungkan rasa dorongan yang ada pada Dynand Fariz dan kemudian didukung dengan muculnya perasaan yang kuat untuk memilih fashion sebagai hal yang dipilih.

Imajinasi, ciri imajinasi berhubungan dengan citacita yang ingin dicapai. Dalam hal ini Dynand Fariz memiliki imajinasi dan fantasi untuk membuat sebuah karnaval fashion yang besar dan megah. Adanya ciri tersebut menunjukkan bahwa Dynand Fariz mampu berfikir melampaui batas, ide yang terfikirkan belum pernah dipikirkan orang lain sehingga sifatnya orisinal.

Estetika, dalam hal ini estetika yang dimaksud adalah gagasan estetik yang dimiliki oleh Dynand Fariz, atau lebih mengarah pada tingkatan persepsi keindahan yang dimiliki Dynand Fariz. Melihat dari hasil karya yang telah dibuat oleh Dynand Fariz, yaitu konsep JFC dan prototype JFC 1- 14 membuktikan bahwa Dynand Fariz memiliki standar estetika yang tinggi. Kesadaran akan standar estetika diperoleh melalui penghayatan, bukan semata melalui pengertian, pemahaman ataupun kesadaran (Tabrani, 2006: 247). Kesadaran estetika Dynand Fariz didapat melalui pengalam penghayatan yang telah dialami. Dynand Fariz mendapatkan pengalaman pengahayatannya dalam bidang fashion ketika dia melakukan studi di ESMOD Jakarta dan ESMOD Perancis, dan pengalaman tersebut tidak bisa diragukan mengingat ESMOD merupakan sekolah fashion yang bertaraf Internsional.
Sikap keterbukaan, ciri sikap keterbukaan dapat dilihat ketika Dynand Fariz dapat menerima kritik dan saran dengan bijak. Keberlangsungan pertunjukan JFC banyak mengalami halangan dengan larangan dan kritik daari berbagai kalangan, akan tetapi hal tersebut dapat diterima secara terbuka oleh Dynand Fariz. Sikap terbuka tersebut dilakukan dengan menerima pendapat orang lain walaupun berbeda prinsip, namum hal tersebut justru dimanfaatkan oleh Dynand fariz sebagai proses integrasi untuk menjadikan JFC dapat diterima oleh masyarakat luas.

Keberanian, ciri tersebut dapat dilihat bagaimana Dynand Fariz berani dalam memiliki ide besar membuat karnaval fashion dan berani untuk mewujudkan ide tersebut. Sifat keberanian yang dimaksud dalam hal ini haruslah memiliki dasar alasan yang kuat dan terarah. Dynand Fariz berani dalam mewujudkan idenya dengan dasar alasan yang kuat yaitu ingin membuat Jember sebagai kota karnaval kelas dunia.

Spontan, merupakan ciri terakhir yang dimiliki manusia kreatif, spontan yang dimaksud adalah kepekaan terhadap isu global yang sedang terjadi, sehingga mampu menangkapnya fenomena tersebut dan kemudian dijadikan sebagai ide. Dynand Fariz memiliki kepekaan terhadap isu yang sedang terjadi sehingga hal tersebut menjadi inspirasi Dynand Fariz untuk mengkonsep tema JFC sesuai dengan isu yang sedang terjadi. Hal ini terbukti dengan bergantinya tema JFC dalam setiap tahunnya, dan tema yang diangkat selalu tema-tema mengacu pada isu yang aktual.

Keseluruhan uraian di atas membuktikan bahwa Dynand Fariz merupakan manusia yang kreatif dan inovatif. Dynand Fariz mampu mengkontruksi pemikirannya sehingga menjadi ide besar. Ide besar yang dimiliki Dynand Fariz wujudkan dengan berani dengan penuh sifat keterbukaan, sehingga berdampak pada kelangsungan dan eksistensi JFC hingga saat ini.

Sifat kreatif dalam Dynand Fariz tersebut, secara tidak langsung menjadikan Dynand Fariz sebagai faktor yang mendominasi dalam JFC. Hal tersebut terjadi karena konsep awal perancangan pertunjukan berasal dari ide kreatif Dynand Fariz. 
Dynand Fariz telah membuat sebuah karya baru dalam dunia seni, yaitu sebuah karnaval fashion yang didalamnya terkandung unsur seni rupa bergerak. Seni rupa bergerak yang dimaksud adalah lukisan busana yang dilukis dan didesain oleh Dyannd Fariz, kemudian diwujudkan dalam bentuk yang sama persis dengan lukisannya, dan dipergakan oleh model dengan atraksi yang dikolaborasikan dengan unsur seni lain yaitu, drama, tari dan musik.

Dalam proses menularkan kreativitasnya terhadap para peserta JFC, Dynand Fariz terjun langsung dalam proses pelatihannya yaitu in house training JFC. Proses tersebut, secara tidak langsung membuat Dynand Fariz menjadi sosok yang menginspirasi bagi peserta JFC. Gaya Dynand Fariz yang keras dan disiplin pada saat mengajar secara langsung, tidak hanya sekedar menginspirasi akan tetapi juga menjadikan dirinya sebagai fasilitator, karena berbagi ilmu dengan para peserta JFC, dan sebagai motivator bagi peserta dalam berkarya seni khususnya dibidang seni rupa dan fashion.

Adanya proses tersebut menjadikan Dynand Fariz sebagai seorang pendidik seni dalam masyarakat, khususnya masyarakat Jember. Dynand Fariz telah membuka sekolah non formal bidang kepelatihan art dan entrepreneur yang dapat diikuti oleh seluruh lapisan masyarakat. Masyarakat yang mengikuti JFC secara gratis mendapatkan pelatihan dan secara tidak langsung mengalami sebuah penularan kreativitas yang dilakukan oleh Dynand Fariz.

\section{Jember Fashion Carnaval (JFC): Produk Seni Pertunjukan yang Memenuhi Misi Kepari- wisataan Indonesia}

Produk wisata yang unggul merupakan sebuah produk wisata yang dapat memenuhi target misi yang sudah dicanangkan oleh pemerintah. Jember Fashion Carnaval (JFC) merupakan salah satu produk wisata yang dapat mencapai target misi kepariwisataan Indonesia. Meskipun dalam pencapaian misi tersebut banyak sekali kendala yang dihadapi, akan tetapi JFC memiliki potensi untuk mencapai target misi tersebut. Hal tersebut dibuktikan dengan bertambahnya prestasi yang diperoleh oleh JFC. Oleh karena itu tidak diragukan lagi apabila Jember Fashion Carnaval (JFC) disebut sebagai sebuah produk pariwisata yang unggul dalam industri pariwisata di Jember.
Berikut 4 misi kepariwisataan indonesia menurut Muljadi yang berhasil dicapai oleh JFC:

a. Pemberdayaan dan peningkatan peran serta masyarakat dalam pengembangan kepariwisataan.

Jember Fashion Carnaval (JFC) merupakan sebuah produk wisata berupa pertunjukan karnaval seni yang dilakukan di luar ruangan, dimana dalam setiap pergelaranya melibatkan banyak pihak. Dalam hal ini JFC melibatkan banyak pihak yaitu seluruh lapisan masyarakat Jember, baik peserta, relawan, penonton, pemerintah, dan lembagalembaga terkait lainnya. JFC berusaha merangkul seluruh lapisan masyarakat agar berpartisipasi dalam pelaksanaan pertunjukannya. Hal ini dibuktikan oleh pihak manajemen JFC dengan tidak memberikan syarat apapun bagi masyarakat yang ingin menjadi peserta JFC, sehingga siapapun boleh menjadi peserta untuk mengikuti JFC.

Peningkatan dan pemberdayaan peran serta masyarakat yang dilakukan menjadi salah satu aspek penting untuk keberlangsungan JFC. Dimana seluruh lapisan masyarakat Jember saling bersinergi untuk mendukung berlangsungnya pertunjukan. Berikut gambar skema peran serta masyarakat yang mendukung pelaksanaan JFC:

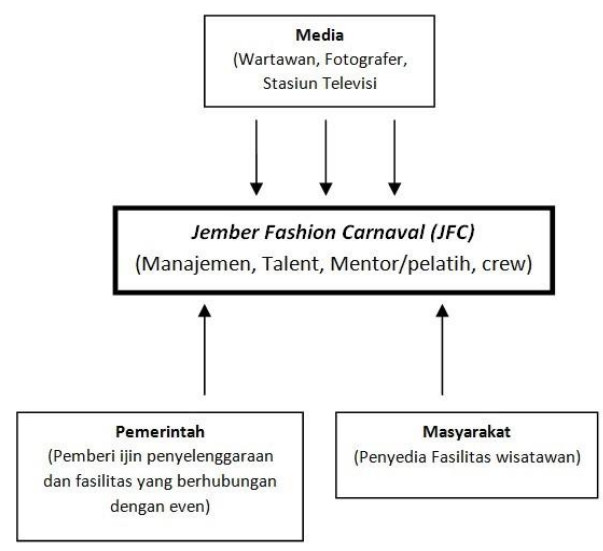

Gambar 1. Bagan Relasi Pendukung JFC (dok. Chandra, 2014)

Gambar bagan di atas menjelaskan bagaimana JFC melibatkan peran serta masyarakat dalam pelaksanaannya. Terjadi sebuah hubungan yang saling bersinergi yaitu, antara masyarakat yang menyediakan fasilitas bagi wisatawan yang ingin menyaksikan pertunjukan JFC secara langsung, dan dukungan pemerintah Jember yang memberikan ijin penyelenggaraan acara dan fasilitas yang dibutuhkan. Hal ini membuktikan bahwa JFC 
memberdayaan dan meningkatkan peran serta masyarakat dalam pengembangan kepariwisataan Jember.

b. Pemanfaatan kebudayaan untuk kepariwisataan guna kepentingan agama, pendidikan, ilmu pengetahuan, ekonomi, persatuan dan kesatuan, serta persahabatan antar bangsa.

Pelaksanaan misi kedua kepariwisataan indonesia ini menjadi dasar Jember Fashion Carnaval (JFC) dalam melangkah menuju visi, misi dan konsep 4E JFC yang sudah diungkapkan di bab sebelumnya. Dalam perjalanannya JFC selalu mengedepankan dalam mengembangkan pendidikan, agama, kesenian, budaya, dan perekonomian.

Dalam hal peningkatan pendidikan terlihat pada pendidikan kepelatihan yang dilaksanakan sebelum pergelaran JFC berlangsung. Peserta diberikan in house training selama kurang lebih 6 bulan untuk persiapannya. Dimana dalam in house training tersebut akan mengasah kreativitas peserta sehingga peserta dapat mengembangkan keahlian yang sudah dilatihkan.

Selain itu dalam agenda BBJ pada acara MTQ se-Jawa Timur tahun 2009 JFC juga berpartisipasi menampilkan kreasi busana pada baliho/banner yang bernuansa islam sehingga unsur agama atau kota santri Jember masih dipertahankan sesuai dengan visi misi yang ditargetkan.

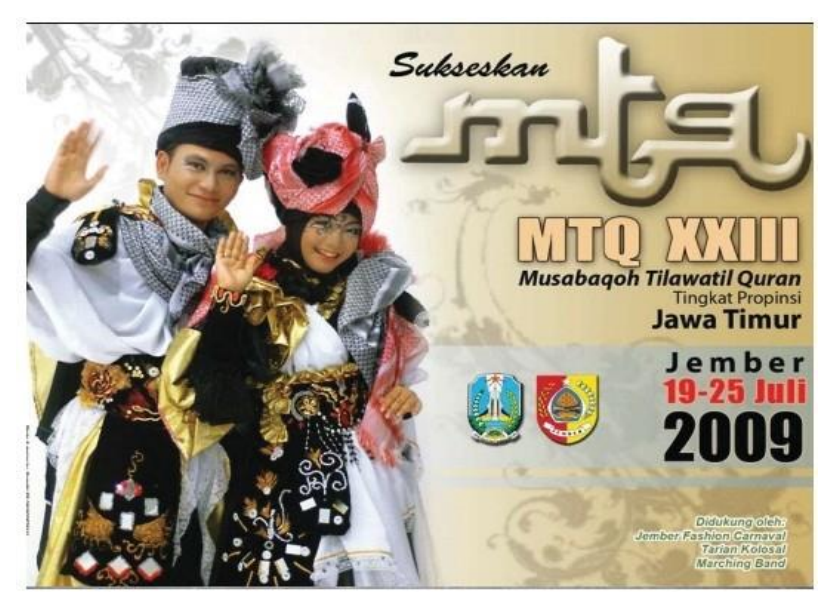

Gambar 2. Baliho MTQ se-Jawa Timur tahun 2009 (Dok. Majalah Halo Jember, 2014) c. Pengembangan produk kepariwisataan yang berwawasan lingkungan bertumpu pada budaya daerah, pesona alami pelayanan prima, dan berdaya saing global.

JFC sebagai produk pariwisata unggulan dalam memelihara dan mengembangkan potensinya, pihak manajemen JFC setiap tahunnya selalu memberikan kemasan tampilan pertunjukan yang berbeda dari tahun sebelumnya, sehingga JFC selalu memiliki kreasi baru yang dapat menarik perhatian wisatawan dan mempunyai daya saing global. Salah satu perwujudan dalam memperbarui tampilan kemasan pertunjukannya adalah dengan memilih tema yang berbeda pada tahun sebelumnya. Konsep tema yang diambil dalam setiap tahunnya selalu mengacu pada fenomena global yang sedang terjadi, akan tetapi pemilihan tema tersebut tetap bertumpu pada budaya daerah, pesona alami dan norma yang berlaku pada negara Indonesia.

Pelayanan fasilitas dalam mengakses JFC setiap tahunnya menunujukkan peningkatan, salah satu contohnya dengan diadakannya tribun penonton dan tribun fotografer. Selain itu pada JFC 2015 pada area catwalk diberikan pagar hingga titik area 3 kilometer, hal ini memudahkan para peserta untuk malakukan runway, dan lebih menertibkan penonton. Sehingga memberikan akses kemudahan bagi para peserta maupun penonton, serta menunjukkan pada masayarakat bahwa JFC merupakan event karnaval kelas dunia, yang mempunyai daya saing global.

d. Pengembangan SDM kepariwisataan yang sehat, berakhlak mulia dan profesional yang mampu berkiprah di arena internasional.

Dalam hal pengembangan SDM kepariwisataan, JFC selalu melakukan inovasi mengacu pada visi dan misi yang sudah diungkapkan, sehingga JFC bersaing secara sehat dengan mempertaruhkan kreatifitas mendesain busana Dynand Fariz dan pesertanya serta keprofesionalitasan pihak manajemen JFC dalam mengelola acara. Sehingga dengan menjaga kualitas kreativitas peserta, manajemen pengelolanya JFC, serta selalu melakukan inovasi dalam setiap pertunjukannya, JFC dapat terus berprestasi hingga internasional seperti halnya saat ini. 


\section{SIMPULAN}

Sejarah terbentuknya JFC di Kabuapaten Jember dipengaruhi oleh beberapa faktor. Selain faktor Dynand Fariz yang merupakan sosok kreatif dan merupakan putra daerah asli Jember, keadaan sosial masyarakat Jember menjadi faktor tumbuh dan bekembangnya JFC. Masyarakat Jember yang berlatar belakang masyarakat pandalungan, menyikapi JFC dengan terbuka, meskipun beberapa ada yang memberikan tanggapan negatif, akan tetapi JFC berhasil meyakinkan dan bernegosiasi secara damai. Selain itu faktor pendukung lain adalah adanya persaingan dalam dunia pariwisata antar daerah, sehingga JFC mengisi peluang tersebut dengan menjadikan Jember sebagai salah satu kota kreatif di Jawa Timur. JFC secara nyata dapat membuktikan dapat memenuhi visi dan misi kepariwisataan Jember bahkan Indonesia sehingga menjadi identitas bagi Kota Jember. Dunia pariwisata Kabupaten Jember berkembang dan meningkat setelah adanya JFC. Keberadaan JFC menarik banyak wisatawan dalam maupun luar negeri untuk datang ke Jember. JFC mempunyai daya tarik tersendiri bagi para wisatawan hal ini dikarenakan JFC memiliki keunikan salah satunya adalah memamerkan busana yang indah dijalanan. Sehingga hal ini berdampak pada meningkatknya PAD Kabupaten Jember.

Selain itu berkembangnya JFC menjadikan masyarakat dan pemerintah sadar bahwa perlu adanya dukungan peningkatan infrastruktur, salah satunya dalam menyediakan fasilitas umum. Sehingga pemerintah memperbaiki fasilitas kota yang kurang memadai, dan menarik banyak investor agar menanamkan modal di Jember.

Selain menjawab pertanyaan rumusan masalah yang telah diungkapkan, penelitian ini menunjukkan bahwa dalam proses terbentuknya JFC terdapat sebuah pola penurunan kreativitas didalamnya. Proses tersebut berawal dari proses kreativitas individu Dynand Fariz, kemudian melalui pelatihan in house training terjadi proses pemebelajaran tersampaikan kepada peserta JFC, sehingga bersifat kreativitas massal. Adanya proses kreativitas massal tersebut mengakibatkan terjadinya sebuah produktivitas massal, yaitu pembuatan busana secara bersamaan yang kemudian dipamerkan. Adanya proses kreativitas tersebut, secara perlahan membuat JFC menjadi barang komoditi. JFC berubah menjadi sebuah pertunjukan yang layak jual, bahkan pihak manajemen JFC telah menyuarakan menjual event JFC. Hal ini salah satunya dibuktikan dengan adanya penjulan tiket tribun pada saat pertunjukan dilaksanakan. Sehingga dalam hal ini JFC mengalami sebuah proses komodifikasi.

\section{DAFTAR RUJUKAN}

Barker, Chris. 2005. Cultural Studies, Teori dan Praktik (terjemahan). Yogyakarta: PT. Bentang Pustaka.

Barnard, Malcolm. 2011. Fashion sebagai Кomunikasi, (Cara Mengkomunikasikan Identitas, Sosial, Seksual, Kelas, dan Gender). Yogyakarta: Jalasutra.

Bourdieu, Pierre. 2010. Arena Produksi Kultural, Sebuah Kajian Sosiologi Budaya. Bantul: Kreasi Wacana.

Bungin, Burhan. 2001. Metodologi Penelitian Sosial, Format-format Kuantitatif dan Kualitatif. Surabaya: Airlangga University Press.

Cakwigi. 2013. (2013, Januari 21). Jember Fashion Carnaval 2013 dari Rakyat Untuk Indonesia. Diperoleh dari cakwigi@blogdetik.com.

Jenkins, Richard. 2004. Membaca Pikiran Pierre Bourdieu. Yogyakarta: Kreasi Wacana.

Jenks, Chris. 2013. Culture Studi Kebudayaan. Yogyakarta: Pustaka Pelajar.

Kutha Ratna, Nyoman. 2010. Metodologi Penelitian, Kajian Budaya dan Ilmu Sosial Humaniora pada Umumnya. Yogyakarta: Pustaka Pelajar.

Mardiana Pambudy, Ninuk. (2011, Oktober 7). Mimpi Fariz Memeluk Dunia. Diperoleh dari tulisaninspiratif.wordpress.com.

Mc Robbie, Angela. 2011. Postmodernisme dan Budaya Pop. Bantul: Kreasi Wacana.

Muljadi, A.J. 2009. Kepariwisataan dan Perjalanan. Jakarta: Rajagrafindo Persada. 